Copyright (C) 2017 by Academic Publishing House Researcher

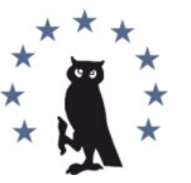

Published in the Russian Federation

European Researcher. Series A

Has been issued since 2010.

ISSN 2219-8229

E-ISSN 2224-0136

2017, 8(4): 285-296

DOI: $10.13187 /$ er.2017.4.285

www.erjournal.ru

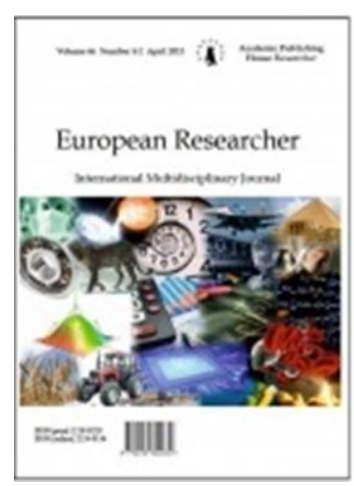

UDC 792.09; 792.03

\title{
The Interaction of Provincial Drama and the Capital Scene: the Historical and Theatrical Aspect
}

\author{
Vera K. Krylova ${ }^{\text {a, * }}$

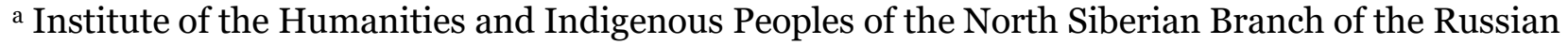 \\ Academy of Sciences, Russian Federation
}

\begin{abstract}
In the article, for the first time, taking into account the assessments of the leading directors and, what is very important, the audience, researched the significance of the playwright A.V. Vampilov in the theater space not only of the former USSR, but also abroad. On the basis of the historical-theatrical method, through the analysis of printed sources, which included records from rehearsals (in particular, at the St. Petersburg Theater BDT), as well as notes, especially valuable personal observations of the coryphaeus of Soviet direction G.A. Tovstonogov and other directors about the playwright's work, showed the role of his healing provincial reality endowed with "moral confession". It is no accident that the emphasis is placed on the performance "Last summer in Chulimsk", which had a special psychological impact not only on the provincial, but also on the metropolitan viewer. In the conclusion emphasized the gracious role of Vampilov's "soviet hinterland", which was perceived almost with children's immediacy by the audience and transformed the actions of the heroes into the inner feelings of everyone sitting in the hall. Also, one can not but admit that even today the world of the "Soviet province" Vampilov has not lost its significance. It is still in demand, it needs both theaters and spectators. For some, it is important for an original, multifaceted, bright artistic phenomenon in the theater space, for others - with the healing purity of human feelings, having experienced that, "I want to embrace the whole world, create, live, love and believe!".
\end{abstract}

Keywords: dramaturgy Vampilov, performance "Last summer in Chulimsk", director G.A. Tovstonogov, stage performance, spectator psychology, Theatrical art.

\section{1. Введение}

Термин провинция «прочно обосновался в нашем языке, а в отечественной беллетристике и научной литературе стали множиться рассуждения о противоположности центра, столицы, с одной стороны, и периферии, провинции - с другой. Отсюда часто возникающие вопросы. Что же является подлинным центром, или балансиром, русской жизни - провинция или столица? Где коренятся настоящая духовная жизнь, сакральная традиция, русское самосознание? Редкий отечественный интеллектуал не задавал этих и

\footnotetext{
${ }^{*}$ Corresponding author

E-mail addresses: kvkrepressgur@mail.ru (V.K. Krylova)
} 
похожих вопросов, принимая то сторону провинции, то - столицы» (Уничтожьте в себе провинцию, 2009).

В тоже время, каждый по-своему воспринимал, воспринимает и будет воспринимать как провинцию, так и столицу. К примеру, М.Е. Салтыков-Щедрин в «Письмах о провинции» определял ее как «среду, в которой собираются подати и налоги, необходимые для безостановочного действия центров и как кузницу того сокровенного, которое, как правило рождается именно в провинции» (Салтыков-Щедрин, 1969). Но сегодня речь не о той провинции, в которой «налоги собирают». Не о ее экономической и территориальной значимости как таковой. А о той, в которой рождается то самое «сокровенное», способное облагородить столицу. Как на этой почве взаимодействуют между собой столица - провинция. Остановимся не на общих вопросах, а на конкретном примере - творчестве провинциального драматурга А.В. Вампилова с акцентом на его пьесу «Прошлым летом в Чулимске» и ее сценической значимости, как для столичных, так и провинциальных театров.

Но прежде чем ответить на вопрос была ли востребована тема провинции в лице А.В. Вампилова столичными театрами и столичными зрителями, как происходило взаимодействие, в начале несколько слов о тех исследователях, которые посвятили этому автору ряд своих научных изысканий вне сферы театральной деятельности. Среди них работа «Женские образы в драматургии А.В. Вампилова» (Шин Янг Ми, 2002). В ней автор рассматривает эволюцию женских образов, а через их речевую характеристику выявляет авторскую позицию. О.В. Чербаева обратила особое внимание на «природного человека» охотника Еремеева в образной структуре пьесы «Прошлым летом в Чулимске», который по ее мнению, связан с природой и также всецело растворен в ней» (Чербаева, 2014).

Отдавая дань уважения своему земляку, иркутские ученые и их коллеги из других городов (Гушанская, 1990) раскрывали и анализировали «Мир Александра Вампилова», изучали его «Жизнь. Творчество. Судьбу» (Мир Александра Вампилова..., 200о), вникали в творческую лабораторию драматурга (Смирнов, 2006). А исследователи Н.М. Кузнецова (Кузнецова, 2012) и ее коллега из Томска А.С. Собенников (Собенников, 2002) посвятили свои работы двум финалам пьесы «Прошлым летом в Чулимске».

Однако, никто из названных авторов, не акцентировал свое внимание на означенной нами теме. Не задавался вопросом, каким образом провинция в лице этого талантливого драматурга взаимодействовала со столичной сценой. Ведь такое явление, как драматургия А.В. Вампилова, должна была заинтересовать не только литературоведов, но исследователей других направлений, и прежде всего театр. Потому что любой «театр не может существовать без пьесы, как ваятель - без гипса, как хлебороб без земли и семян» (Товстоногов, 1980). И еще потому, что сферы деятельности, в которых художник предпринимает исследование человеческой души предельно многообразны, ибо «великий художник всегда опережает время».

В 1970-е годы его имя было достаточно известно не только в СССР, но и за рубежом. Особый интерес вызывала пьеса «Прошлым летом в Чулимске». Трудно найти столичный театр, который бы не включил ее в свой репертуар и через действующих лиц не отразил на сцене суть, содержание, проблемы сибирской провинции. О том, как родилось это самое сокровенное в провинции, как оно покорило столицу и попытаемся раскрыть на примере популярности и востребованности на столичных сценах спектакля «Прошлым летом в Чулимске» по одноименной пьесе драматурга А.В. Вампилова.

\section{2. Методика исследования}

Для того, чтобы более достоверно была представлена картина жизни вампиловских героев, обратимся к мнению не только исследователей, ведущих режиссеров, но и к самому главному барометру популярности драматурга - оценкам спектакля зрителями, зафиксированными средствами массовой информации. Какое влияние провинциальные герои пьесы А.В. Вампилова «Прошлым летом в Чулимске» оказывали на столичную зрительскую аудиторию? Как? Каким образом душевное озарение Вампилова, воплощенное им в драматургическое произведение и освещенное гением режиссера, талантом исполнителей могло влиять на зрительское восприятие? И влияло ли? В этом и попытаемся разобраться. 


\section{3. Обсуждение и результаты}

Известно, что в 1970-е гг. даже столичным театрам страны, и в том числе великому режиссеру XX века Г.А. Товстоногову, «как и многим его коллегам по искусству режиссуры и художественному руководству театрами, частенько не доставало того драматургического материала, который бы идеально мог совпадать с мыслями современника и его жаждой ответить на вопросы времени. И, тем не менее, однажды это произошло. Новый жизненный материал, содержащийся в пьесах А.В Вампилова, своей трактовкой оказался родственным режиссеру с идейно - творческой позиции. Поэтому в Большом драматическом театре (БДТ) и были поставлены две его пьесы: на малой сцене - “Провинциальные анекдоты” (1972 г.), на большой “Прошлым летом в Чулимске" (1974 г.)» (Рыбаков, 1997).

Почему же прославленный режиссер северной столицы решил искать необходимый драматургический материала, который бы идеально мог совпасть с мыслями современника именно в провинции? И чем провинция в лице А. Вампилова могла «ответить» на вопросы, стоящие перед ним и театральным сообществом? Что нового провинциальный драматург мог привнести на столичную сцену? Как ни странно, ответ содержался в самых простых, в равной степени ценимых всеми истинах. В театр драматург пришел не один. Вместе с ним «в него пришли искренность и доброта - чувства давние, как хлеб, и, как хлеб же, необходимые для нашего существования и для искусства» (Распутин, 1992).

Эта, на грани детства, неподкупная искренность, доброта без труда распахнула двери столичных театров, к сожалению, уже после трагической смерти писателя. «Нам удалось доставить ему радость при жизни - мы первые поставили его пьесу "Провинциальные анекдоты”, - с гордостью вспоминал Г.А. Товстоногов. - Он признал наш спектакль “своим”, и наша дружба должна была продолжиться многие годы... Вампилов был неожиданным в каждом драматургическом повороте. А это при безупречной логичности и есть признак большого таланта, открывателя новых путей в искусстве. Ему было всего тридцать пять лет, но он знал жизнь, как мудрец» (Товстоногов, 1980).

Перед репетицией спектакля 24 сентября 1973 г. режиссер, обратил внимание актеров на ту ответственность, которая возложена на исполнителях ролей и акцентировал их внимание на достоинствах драматургического произведения. «Если мы хотим, чтобы наш “Чулимск" был достоин памяти Александра Вампилова, то должны проделать огромную работу, погрузившись в жизнь далекого от нас таежного поселка. При внешнем бытовизме у Вампилова такая незаурядность, такое отличие от привычных нам авторов. И все жизненно правдиво по самому большому счету. Пьеса может показаться пессимистичной, но она вызывает катарсис. Происходит нравственное очищение. У Вампилова герои - это крупные личности, и становятся они таковыми на наших глазах. Это великолепная драматургия, хотя бы потому, что в течении обычных суток происходят события огромной насыщенности, берется высшая точка их взаимоотношений. Необходимо ощутить их реальность, плоть и кровь, их непохожесть на всех остальных людей в мире, их точную социальную и нравственную природу. Отнесемся к этой современной пьесе, как к классике. Она достойна этого» (Товстоногов, 1980). Такой оценки прославленного мастера сцены удостаивался далеко не каждый драматург, пьесы которых шли на сцене театра.

В спектакле участвовали ведущие актеры прославленного театра. Оформил художник Э.С. Кочергин, с которым в «последние годы много и плодотворно работал Товстоногов. Он окружил сцену темными вековыми деревьями, замкнул действие в глуши, создав нечто похожее на “медвежий угол". Здесь художник и режиссер оказались вполне полемичны. Им важно было отгородить пространство, чтобы показать общность, локализовав место событий, открыть их широкий внутренний смысл» (Рыбаков, 1977).

Каким же образом происходило это самое открытие внутреннего смысла на сцене? Лучше всего на этот вопрос могут ответить очевидцы событий режиссер-постановщик и известный российский ученый-театровед Ю.С. Рыбаков, наблюдавший и изучавший творчество режиссера Ленинградского БДТ Г.А. Товстоногова. Отсюда опора на их мнение очевидна. Поэтому мы вновь обратимся к первоисточникам. Взглянем на премьеру спектакля «Прошлым летом в Чулимске» в БДТ глазами очевидца. В тот вечер действие начиналось несколько неожиданно. «Занавес еще был закрыт, но, откуда-то издали, тихо, неторопливо, задумчиво высокий женский голос доносил старую песню “Это было давно, лет пятнадцать назад, вез я девушку трактом почтовым...”. И сама песня, и ее скромное одноголосие как 
нельзя лучше подходили к местному, сибирскому колориту, придавали зачину спектакля дух естественного демократизма. Вместе с ней зал наполнялся какой-то щемящей тревогой, предчувствием чего-то неожиданного.... Затем эту песню, вынесенную режиссером в качестве эпиграфа к спектаклю, между делом напевали его герои, жители маленького таежного райцентра. Под нее же они решали свои личные и семейные дела, которые под пером писателя и взглядом режиссера, обретали для зрителей значительный нравственный смысл» (Рыбаков, 1977).

В последующем, на протяжении всего спектакля, посредством пристального внимания к малейшему душевному повороту, каждому жесту и взгляду, на сцене выстраивалась «естественная и абсолютная достоверность» событий всего происходящего. И делалось это для того, чтобы через все сложности сюжета, взаимных обид и претензий героев подвести зал к главной мысли, к главному событию, основанному на их взаимоотношении. При котором Валентина тихо и безответно любит Шаманова, а ее любит сын Анны Пашка, приехавший сюда на время из города. Он любит давно, тяжко, властно, как собственник, как удачливый человек. Воспользовавшись стечением обстоятельств, Пашка овладевает Валентиной, которая в этот момент потеряла всякую веру в смысл жизни, ибо ей показалось, что Шаманов ее обманул - пообещал прийти на свидание - и не пришел.

Словом, все сюжетные мотивы спектакля, весь пафос автора и режиссера звучали призывом к чуткости, доброте, духовности. В это широкое понятие эмоционально: конкретно входила и драма Шаманова. И драма одиночества Мечеткина, Анны и Афанасия, который, любя жену, никак не может простить ей, или хотя бы, не напоминать, что Пашка не его сын. Как видно, у каждого героя своя сложная сценическая жизнь.

Имелась она и у охотника Ильи Еремеева, хотя на первый взгляд, его история кажется, ничем не примечательна. Но актер О. Борисов совместно с режиссером настолько обогатили сценический образ старого эвенка, что «перед зрителями предстал полноценный, на редкость интересный, притягательный, полный трогательной и мудрой непосредственности, сроднившийся с природой, человек. Охотник был наделен неподдельной гордостью человека привыкшего жить один на один с природой» (Цимбал, 1977). Становится понятно, что ни режиссер, ни актеры, ни театр, не пропустили ни единого штриха в духовной биографии каждого из героев. Даже самые маленькие истории жителей Чулимска, случившиеся прошлым летом, в конечном итоге, вывели зрителей к глубоким и сложным нравственным проблемам окружающего мира. И к драме Валентины Товстоногов относился, как к трагедии. Это было его жанровым решением. Потому спектакль и возвысился «до внутренней трагедийности».

Иначе и не могло быть, потому что эта самая «внутренняя трагедийность», вытекала из обостренного отношения к самой сердцевине пьесы А.В. Вампилова, из ее нравственного максимализма, который проверялся образом Валентины и воплощался в этом характере. «Трагический, идеальный, он был призван контрастировать с тем глухим бытом отношений и мировосприятия, которые царят вокруг девушки» (Седых, 1974). Это вполне закономерно. Потому что «самый сильный сигнал тревоги в искусстве дает трагедия».

В первую очередь это понимал и чувствовал Г.А. Товстоногов, потому и остановил свой выбор на этой пьесе. Богатый режиссерский опыт позволил ему безошибочно предвидеть, по достоинству оценить ее успех и благотворную силу воздействия на зрителей. «По моему убеждению, пьеса Вампилова... почти совершенство. Когда над ней работал, мне казалось, что там нельзя убрать даже запятой. Поэтому, без преувеличения, относился к ней, как к пьесе Чехова или Горького» (Товстоногов, 1980). Факт более чем красноречивый. Поставив Вампилова рядом с такими признанными знатоками театра, тем самым драме «Прошлым летом в Чулимске» был дан старт не только на всесоюзную, но и мировую сцену.

C таким же уважением эту пьесу восприняли в Ленинградском академическом театре имени Ленсовета, премьера которой состоялась в 1983 г. а на сцене театра им. В.Ф. Комиссаржевской 6 декабря 2014 г. Постановку осуществил засл. деят. искусств России С. Афанасьев, сценография засл. худ., лауреата Гос. премии России А. Орлова, худ. по костюмам Н. Дружкова. Как современный зритель воспринял до перестроечную провинциальную действительность, время молодости своих отцов и матерей?

Спустя сорок с лишним лет, в связи со сменой нравственных ориентиров в обществе, здесь чулимская история получила несколько иное, авторское звучание: максималистка 
Валентина сводила счёты с жизнью, попранной людской бездумностью... В спектакле Валентина (Е. Нилова) начинала петь, «Мне снится, будто я от поезда отстал» (тоже) ещё до начала действия (только не за сценой, а) на авансцене. «А дальше - речь только о хрупкости чужого человеческого мира, вторгаясь в который люди всегда думают лишь о себе и почти никогда о том, чей духовный, внутренний суверенитет они нарушают...» (Омецинская, 1975). На роль Шаманова в театр был приглашен актер А. Кудренко из БДТ, который воплотил на сцене «одного из галереи мучающихся своей опустошенностью вампиловских героев».

Для театра им. В.Ф. Комиссаржевской спектакль «Прошлым летом в Чулимске» стал очередной ступенью роста профессионального мастерства. Он был удостоен высшей театральной премии Санкт-Петербурга «Золотой софит» (сезон 2014-2015) в трех номинациях: «Лучшая женская роль» (Е. Нилова - Валентина), «Лучшая мужская роль» (А. Кудренко - Шаманов), «Лучшая работа художника» (А. Орлов - сценография)

Таким образом, взяв за основу то самое «сокровенное чувство», театр преподносил зрителям «правду жизни, передавал голоса живых людей, которые не борются, не защищают свои права, а просто принимают все происходящее. Эта простота и есть подлинная глубина их жизни. Кто-то их осудит, кто-то узнает самого себя, но вряд ли Чулимск кого-нибудь оставит равнодушным» (В театре Комиссаржевской..., 2014). Работая над спектаклем, реж. С. Афанасьев был уверен, что постановка заставит зрителя поразмышлять о чувствах и том, что делает современных людей похожими на героев пьесы. И надо сказать, что в этом он не ошибся. Это ли не доказательство того, что провинция всецело покорила северную столицу.

А что со столицей нашей Родины Москвой? Посмотрим, смог ли Вампилов покорить и ее сценическое пространство?

В том же 1974-м. к его творчеству обратился Московский театр имени М. Ермоловой реж. В. Андреев, худ. А. Окунь осуществили постановку пьесы «Прошлым летом в Чулимске». В то же время ее премьера состоялась в Современнике - реж. В. Фокин, худ. П. Кириллов, музыка В. Дашкевича. В 2005 г. пьеса появилась на сцене театра имени Вахтангова под названием, «Чулимск прошлым летом», реж. Д. Петрунь, сценография и костюмы худ. М. Обрезкова. В нем изгородь заменяли подсолнухи. В финале по принципу «повешенного» ружья в первом действии, как и завещал великий Чехов, из него Валентина и выстрелила.

А в 2012-м эта пьеса была поставлена в Новом театре Москвы и Московском драмтеатре им. А.С. Пушкина, реж. спектакля Игорь Бочкин, оформил худ. С. Зограбян. Для того, «чтобы блеснуть в одной из лучших мужских ролей русского репертуара», в нем режиссер сыграл главного героя - Шаманова, тем самым «осуществил актерскую мечту о роли “чулимского Гамлета”, решающего личный экзистенциальный вопрос “быть или не быть?” Плыть по течению жизни, предав свои убеждения и сломав себя как личность? Или все же, встать на путь борьбы с сильными мира сего, оставшись верным себе и собственному делу?» (Сайт Ваш досуг..., 2016).

По окончании представления благодарные зрители оставили свои многочисленные восторженные отзывы: «Очень хороший спектакль! Вечная тема любви и счастья! Так и хочется громко крикнуть - Браво!!!». И действительно, «хороший» «спектакль - это не только то, что творится на сцене, но и то, что рождается в зрительном зале... Как правило, откровенные зрительские отклики подтверждают, сколь глубоко он способен затронуть их, можно сказать, перевернуть душу» (Иванов, 2014).

Отработав на своей площадке, театр показал спектакль на сцене Иркутского драмтеатра. Исполнители понимали, что играть пьесу на родине автора - большая ответственность. Но эти переживания были напрасными, зрители очень хорошо приняли постановку. В зале - полный аншлаг, вместе с актерами публика смеялась и плакала, а в финале стоя аплодировала всему составу и, конечно же, исполнительнице роли Валентины Натальи Рева.

В Московском Художественном театре им. А.П. Чехова премьера новой версии спектакля «Прошлым летом в Чулимске», состоялась под занавес 114-го театрального сезона 4 июня 2012 г. в постановке известного режиссера и актера Сергея Пускепалиса, худ. А. Вотяков. Под «новой» версией подразумевалось, что его финал не будет трагическим и Валентина не кончит жизнь самоубийством, а сценическая история завершится 
оптимистически. По мнению режиссера «оптимистический финал был выбран в связи с тем, чтобы сказать зрителям: что бы ни случалось, а жизнь не бывает без трудностей, она больше и сильнее. Надежду дарят такие мечтатели о прекрасном, такие неравнодушные и верящие в добро люди, как Валентина» (Курова, 2012).

И еще потому что тема невозможности обретения счастья - вечна... Ведь палисадник, в котором Валентина мечтает увидеть когда-нибудь цветы, - это желание видеть жизнь не такой, какой она является на самом деле. Вот почему зрителю становился понятен кризис, который переживает Шаманов, Утопичность мечты подчеркивает разлитая вода по сцене, «так что актеры вынуждены передвигаться по этой заводи в резиновых сапогах и прыгать по деревянным мосткам, И, в общем, нет никаких сомнений, что эта вода никуда не уйдет, а будет только прибывать, и маки здесь цвести не будут. Но, то упорство, с которым Валентина держится за свою мечту, вызывает симпатию. И чувство, которое она испытывает к Шаманову, - первое, сильное - помогает ей не “погрузиться с головой” в чулимский быт и не уйти под воду» (Шевелева, 2012).

Вообще, следует заметить, что история прошлого лета в Чулимске - это клубок туго переплетенных чувств и тревожных ожиданий, что заставляет вампиловских героев в лице актеров. МХТ им. А.П. Чехова «многое не проговаривать, и не находя подходящих слов это многое “выносить за скобки", что подчеркивает их открытость. Оттого-то по ходу спектакля зрители не раз замирали, а в финале, не скрывая своих эмоций, под гром аплодисментов зал долго скандировал: “Бра-а-во!!! Браво-о-о!!!” (Власова, 2013). А по окончании спектакля благодарили за идеально воссозданную атмосферу чулимского лета, в котором «и чеховская тоска, и настроение, и безысходность, и недосказанность, полутона и внутренний конфликт. Все это не может не вызывать зрительский катарсис. После спектакля, дающего столько надежды, на душе становится так легко и так светло! Хочется обнять весь мир, творить, жить, любить и верить! Потому что понимаешь главную мысль спектакля, очень простую: доброта, духовная красота и вера в лучшее - это то, на чем держится наш мир. И будет держаться всегда» (Еремина, 2012). Спектакль находится в репертуаре. С ним театр выезжает на гастроли, значит, и духовная поддержка зрителями будет обеспечена. Это ли не доказательство таланта провинциального драматурга, захватившего сердца столичных зрителей.

Надо полагать, что в Нижегородском академическом театре драмы им. М. Горького зрители тоже получили не меньшее удовольствие от просмотра спектакля «Прошлым летом в Чулимске». Его премьера состоялась в канун дня Победы 8 мая 2008 г. в режиссуре А. Кладько, худ.-постановщик Б. Шлямин, худ. по костюмам Н. Белова. Остановимся на нем, посмотрим, как здесь зритель воспринимал вампиловских героев? Чем же эта пьеса привлекла постановщиков и зрителей?

Как ни парадоксально - своей «нравственной исповедальностью». А все потому, что, как уже говорилось и, судя по информации, содержащейся на сайте театра, в своем творчестве Вампилов унаследовал многие литературные традиции - от Чехова до Володина - но пришёл в драматургию со своим собственным миром: миром «советской глубинки», где тоже есть люди. Они тоже влюбляются и страдают, лелеют свои надежды и разуверяются. У автора нет Героев и Негодяев, нет наставлений и практических советов. Центральная категория его драматургии - это Человек. Всё остальное служит пониманию этого человека, его чувств и мечтаний. Это неоднократно подчеркивал и выдающийся писатель, современник Вампилова Валентин Распутин, говоря о его творчестве. «...Главный вопрос, который постоянно задает Вампилов: останешься ли ты, человек, Человеком? Сумеешь ли ты превозмочь всё то, лживое и недоброе, что уготовано тебе во многих житейских испытаниях?» (Распутин, 1992).

Чем еще так тронула эта последняя и одна из самых светлых пьес Вампилова, поражающая глубокой жизненной достоверностью, знанием человеческого сердца? Возможно тем, что Шаманов решает личный экзистенциальный вопрос: плыть по течению жизни, предав свои убеждения и сломав себя как личность? Или все же встать на путь борьбы с сильными мира сего?. Но при этом остаться верным себе и собственному делу? Ведь именно к этому он и идет сквозь весь сюжет, населенный людьми, решающими для себя похожие вопросы. К тому же «все эти люди абсолютно потеряли голову от любви. Сердце каждого охвачено безнадежной и неутолимой страстью - на сцене создается атмосфера тотального сердечного полыхания, столь свойственного русской жизни. Подруга 
Шаманова Зина - экзальтированная, одинокая, ещё молодая женщина, обманутая в своих чувствах. Юная Валентина - это образец затаенной первой любви. О мужской безответной страсти рассказывает юный возмутитель спокойствия Пашка, влюбленный в Валентину. А его мать вместе со своим мужем - это пример любви-непонимания двух людей, пожизненно обреченных изматывать друг друга то любовью, то ненавистью. Жаждет высокого чувства и смешной нелепый человек Мечеткин, которому тоже не везёт в любви. В центре же всего - Шаманов, экспрессивный и горячий, непредсказуемый и роковой, - в которого влюбляются женщины, но который сам давно разучился любить» (Нижегородский академический..., 2016).

По словам А. Кладько, коллектив театра долго искал пьесу. В результате остановились на «Чулимске» еще и потому, что сам режиссер был влюблен в то время, и испытывал определенную ностальгию по той эпохи. Но, удивительно то, что, глядя на сцену, создается впечатление современной жизни и пьеса тоже оказывается, вполне современна. Режиссер и актеры настолько сумели раскрыть замысел автора, что «зрители могли испытать “чувственный ожог" и при этом не терять надежды» (Нижегородский академический..., 2016).

И действительно, в спектакле, поставленном в русле «эстетики психологического реалистического театра», эта надежда была сохранена. В рамках задаваемой ситуации, исходя из содержания пьесы, ее чудесным образом доносят актеры, которым режиссер «предоставил достаточно много пространства для самореализации». Тем самым на сцене каждый - из исполнителя воли режиссера, превращался в полноценного соавтора спектакля, творца своего героя, что заставляло зрителей «то улыбаться, то рыдать: так впечатлила их игра актеров. Хотелось бесконечно аплодировать! Все действие просто восхитительно!!!» (Нижегородский академический..., 2016).

Любой театр, включая эту пьесу в свой репертуар, безошибочно актуализировал события чулимского лета, основанные на чувственном поле человека. Поэтому ни в одном из столичных, впрочем, точно также и периферийных театров зрители не оставались равнодушными. Кстати спектакль «Прошлым летом в Чулимске» С. Пускепалис поставил и в Кировском драмтеатре им. А.С. Пушкина, а московская постановка была представлена на сцене Саратовского ТЮЗа (2014). С этим спектаклем МХАТ им Чехова выезжал на гастроли в Курск, где, точно также зрители получили незабываемые впечатления.

В Иркутском драмтеатре им. Н. Охлопкова пьесы знаменитого земляка, практически, не сходят со сцены, периодически возобновляясь в постановках новых режиссеров. Так в 2001 г. герои Чулимска вышли на подмостки под руководством реж. Г. Шапошникова, а затем порадовали зрителей Германии.

Вампиловская пьеса оказалась востребована в Кировском (реж. В.М. Портнов, 1974), Белгородском (реж. В. Стариков), Рязанском (реж. М. Ларин, худ. Н. Бокова, 2012), Шадринском (реж. и худ. В. Лаптев) и многих других драмтеатрах страны, С успехом прошла в Киевском Театре на Подоле (реж. В. Малахов, 2011), Здесь чуткая драма А. Вампилова, поукраински «Минулим літом в Чулимську», давно ставшая современной классикой, «поражала зрителей глубокой жизненной достоверностью, знанием человеческого сердца, нравственным максимализмом, бескомпромиссностью чувств, поистине чеховской требовательностью к человеку и такой же щемящей за него болью» (Спектакль «Минулим літом..., 2016).

Кроме того, пьеса были представлена на сценах союзных республик. В Русском драмтеатре Вильнюса ее постановку осуществил Р. Виктюк. А в токийском театре Тоэн В. Фокин. Театр Гешер (Израиль) включил в свой репертуар не только «Прошлым летом в Чулимске», но и «Старшего сына». К слову сказать, только это его произведение сразу после написания 1971 г. оказалось на подмостках около 30 театров страны, состоялось более 1000 представлений, что обеспечило ему лидерство на театральной сцене. Вообще «за тридцать лет, прошедших после смерти А.В. Вампилова, его произведения были переведены на тридцать один язык мира, не раз переизданы и поставлены в театрах многих зарубежных стран» (Шинг Янг Ми, 2002), Это дало возможность иностранным ученым проанализировать его работы и опубликовать свои монографии (Segel, 1993; Farber, 2001, 2003). И это неоспоримый факт. Он и позволяет сделать вывод, что провинция в лице А. Вампилова «покорила» не только столицу, но и значительную территорию земного шара.

Практически, не отыскать «пустующую» сцену хотя бы одной из республик бывшего $\mathrm{CCCP}$, на которой не была представлена его драматургия. Спектакль «Прошлым летом в 
Чулимске» состоялся на сцене Удмуртского национального театра, реж. Л. Романов, художник Б. Науменко. На примере Валентины и Шаманова вместе с актерами на сцене «они создали то чудо перерождения человеческой судьбы, заложенной Вампиловым, которое откликаясь в сердцах зрителей, исцеляло их души от обыденной отягощающей повседневности, указывало путь к духовному возрождению» (Спектакль Нюлэс..., 2016).

Омский театр Галерка достойно представил последнюю пьесу автора на II фестивале драматургии Вампилова в Иркутске в 1999 г. и получил там Гран-при за спектакль «Прошлым летом в Чулимске». И с тех пор коллектив - постоянный участник этого дорогого для него фестиваля, который уже стал внеконкурсным.

Несмотря на тысячи километровую отдаленность от центра, можно сказать классическую провинциальность, коей является Якутия, любимая пьеса А.В. Вампилова «Прошлым летом в Чулимске» появилась на сцене Русского драмтеатра уже в 1974 г. Практически, наряду с ведущими столичными театрами. Вот и не согласись после этого с мнением В.О. Ключевского, не скажи что «в России центр - (не) на периферии». Автор любил своих героев и пьесу, а потому предусмотрел все. А режиссер А.Н. Дененберг, поставивший этот спектакль вместе с художником А.И. Шапиро, также бережно отнесся к замыслу драматурга.

Вопреки сложившемуся мнению, здесь быт не нес на себе печать захолустья, а представлял нечто вроде «исцеляющей пустони», куда герои подобно Шаманову попадают для переосмысления своей жизни. И то, что персонажи пьесы не рвутся отсюда, а остаются здесь, говорит в пользу целительной силы провинции. Хотя в финале Пашка с Шамановым все же покинут Чулимск, но уедут они отсюда иными. «Так, заурядная вампиловская провинция с почти детской непосредственностью меняла психологию и человеческие качества героев пьесы “Прошлым летом в Чулимске”, трансформируя их внешние поступки во внутренние чувства» (Крылова, 2004).

Уже с первых минут у зрителей не возникало никаких психологических барьеров. «Эта простота устанавливала самый высокий уровень доверия между зрительным залом и сценой. И проблемы вампиловских героев становились его проблемами, его горестями и печалями, радостью и заботой, переживанием и надеждой» (Крылова, 2004: 257). Вот почему никто не мог равнодушно отнестись к натянутым семейным взаимоотношениям между Хороших (В. Мичкова) и Дергачевым (Б. Пеньков), занять одностороннюю позицию по отношению к Пашке, Шаманову (В. Антонов), мечтательной натуре Валентины (Н. Корзина), у которой «все на лице - все ее тайны». Оставить вне поля зрения душевные переживания Шаманова. Их они расценивали не как неудавшуюся карьеру прокурора, или слабость, а как маневр - вынужденное временное отступление для «перегруппировки» духовных и душевных сил. «Герой Валентина Антонова был настолько естествен, что нельзя было не заметить - так может поступать только совестливый, ищущий справедливости человек. И зрители не ошиблись. В финале это и происходило. А бурные аплодисменты, как правило, сдержанных на эмоции северян, подтверждали их активную позицию» (Крылова, 2004: 261-262).

Таким образом, театр свидетельствовал, что добро способно победить зло. «И сколько бы оно ни разбрасывало свои темные тучи, луч света всегда пробьется. Ибо добро не погибает безвозвратно, оно способно возрождаться» (Крылова, 2004: 263). Думается, лучшим доказательством такого возрождения являются приведенные выше данные, которые красноречиво подтверждают факт того, что провинциальная драматургия в лице А.В. Вампилова смогла покорить столицу своей непосредственностью, открытостью, искренностью. В то же время обогатить духовной пищей земляков - преданных ценителей его творчества.

\section{4. Заключение}

Подводя итог, хочется еще раз подчеркнуть значимость драматургии гениального сибиряка, «упрочившего мировую славу русского театра и, оставившего нам удивительное явление под названием “Театр Вампилова”... Его не зря именовали “Душа, надежда и совесть российской литературы”» (Нижегородский академический..., 2016). У него, как у Чехова, главное и важное глубоко скрыто. Его драматургия - это сюжет чувств, а не слов. В силу своего новаторского характера, и прочной связи с русской литературной традицией, «его пьесы не могли не оказать определенного влияния на развитие последующей русской драматургии, а также остаться в стороне от исследовательской мысли» (Моторин, 2002). 
Следует заметить, что «Вампилов один из первых, кто совершил переход от драматургии "производственной" - к “психологической” (Гушанская, 1990). И кто всецело покорил столичную сцену. Наибольшей выразительности в диалогах он добивался не за счет удлинения, а за счет погружения в их внутренний смысл. Именно это и заставляло зрителей не просто созерцать события, происходящие на сцене, а переосмысливать их и пропускать через свое сердце, свое сознание, становиться со-участниками событий. Таким образом, происходила проверка на художественную ценность и подлинность драматургического произведения, которая в разное время и была запечатлена режиссерами, исследователями театра, рецензентами и средствами массовой информации. А, как известно, «эстетическое наслаждение, сопровождающее процесс нашего восприятия произведения, и является свидетельством того, что оно художественно» (Бычков, Маньковская, 2017). Оттого столичные и провинциальные зрители получали положительные эмоции, обретали то духовное состояние, при котором каждому «хотелось обнять весь мир, творить, жить, любить и верить!». Именно она - столь удивительная провинциальная вампиловская искренность, оказалась способной покорить не только столичную, но и мировую сцену.

\section{Литература}

Бычков, Маньковская, 2017 - Бычков В.В., Манъковская Н.Б. Художественность как метафизическое основание эстетического опыта и критерий определения подлинности искусства // Вестник славянских культур. 2017. № 43. С. 223

В театре Комиссаржевской, 2014 - В театре Комиссаржевской готова к показу пьеса А. Вампилова «Прошлым летом в Чулимске». 12.12.2014. URL: http://tvkultura.ru/ (дата обращения 21.03. 2016).

Власова, 2013 - Власова T. «Как я провел «Прошлым летом в Чулимске» // Новые известия 2013. 11 июля.

Гушанская, 1990 - Гушанская E.M. Александр Вампилов: Очерк творчества. Л.: Сов. писатель. Ленинградское отделение, 1990. 320 с. С. 87.

Еремина, 2016 - Еремина М. «Прошлым летом в Чулимске» (История прошлого лета). // Сайт MXT им. А.П. Чехова. URL: http://mxat.ru/ (дата обращения 25. 06. 2016).

Иванов, 2014 - Иванов В.В. Об обновлении документальной базы русского театра XX в.

// Вестник Российского гуманитарного научного фонда. 2014. № 3 (76). С. 172.

Крылова, 2004 - Крылова В.К. «Прошлым летом в Чулимске» // Времен связующая нить...Страницы истории Русского драматического театра в Якутии от истоков до 1990-х годов. Новосибирск: Наука 2004. 380 с. С. 257, 261-262, 263.

Кузнецова, 2016 - Кузнецова Н.М. Два финала пьесы А.В. Вампилова «Прошлым летом в Чулимске (Опыт сравнительно-текстологического анализа URL: http://www.pandia.ru/ (дата обращения 25. 06. 2016).

Курова, 2012 - Курова Н. Новую версию пьесы «Прошлым летом в Чулимске» покажет МХТ им. Чехова. // РИА Новости 2012. 1 июня.

Мир Александра, 2000 - Мир Александра Вампилова: Жизнь. Творчество. Судьба: / Сост. Л.В. Иоффе, С.Р. Смирнов и др. Иркутск. 2000. 448 с.

Моторин, 2002 - Моторин С.Н. Творчество Александра Вампилова и русская драматургия 80-90-х годов XX века. дисс... канд. филол. наук M., 2002. 176 c. URL: http://www.dslib.net/ (дата обращения 20. 06. 2016).

Нижегородский академический, 2016 - Нижегородский академический театр драмы им. М. Горького. Отзыв на спектакль «Прошлым летом в Чулимске». URL: http://nizhniinovgorod.tulp.ru/ (дата обращения 25. 06. 2016).

Никитюк, 2000 - Никитюк T.B. «Прошлым летом в Чулимске» // Мир Александра Вампилова: Жизнь. Творчество. Судьба. Иркутск, 2000.

Омецинская, 1975 - Омецинская E. Там рубят - так с плеча // Невское время. 1975. 15 января.

Распутин, 1992 - Распутин В.Г. Где ты, душа жива? // Литература в школе. М., 1992. № 2. C. 30-33. C. 56,59 .

Рыбаков, 1977 - Рыбаков Ю.С. Г.А. Товстоногов. Проблемы режиссуры. Л.: Искусство, 1977.

Сайт Ваш - Сайт Ваш досуг. URL: http://www.vashdosug.ru/ (дата обращения 27.06.2016). 
Салтыков-Щедрин, 1969 - Салтыков-Щедрин M.E. Письма из провинции Письмо седьмое. // Собр. соч. в 20 томах. М. 1969. Т. 7. С. 258-259.

Седых, 1974 - Седъх М. Удивительный день // Театр, 1974, №9. С. 61.

Смирнов, 2006 - Смирнов С.P. Драматургия А. Вампилова: закономерности творческого процесса. Иркутск 2006. 317 с.

Собенников, 2002 - Собенников А.С. «Прошлым летом в Чулимске» А. Вампилова: два финала // Проблемы литературных жанров. Томск, 2002. Часть 2. С. 184-188.

Спектакль, 2016 - Спектакль «Минулим літом в Чулимську». Киевский академический драмтеатр на Подоле. // Все спектакли. URL: http://kiev.glo.ua/theatre/ (дата обращения 23. 06. 2016).

Спектакль Нюлэс, 2016 - Спектакль Нюлэс кушын лемлет сяська. Ижевск // Сайт Борис-билет. URL: http://www.borisbilet.ru/ (дата обращения 25. 06. 2016).

Товстоногов, 1980 - Товстоногов Г.А. Зеркало сцены. № 1. Л.: Искусство. 1980. № 1, С. 7.

Товстоногов, 1980 - Товстоногов. Г.А. Зеркало сцены. № 2 Л.: Искусство. 1980. с. 222 223, 226.

Уничтожить в себе, 2016 - Уничтожить в себе провинцию // Русский репортер. 2009. № 43. 11 ноября. URL: http://www.rusrep.ru/2009/43/provincialnost_editorial/ (дата обращения 22. 06. 2016).

Цимбал, 1977 - Цимбал С. Олег Борисов. Творческий портрет // Театр. 1977. № 10. С. 187.

Чербаева, 2014 - Чербаева O.B. «Природный человек» в образной структуре пьесы «Прошлым летом в Чулимске» // Филологические науки. Вопросы теории и практики. Тамбов: Грамота, 2014. № 10 (40): в 3-х ч. Ч. II. С. 198-201.

Шевелева, 2012 - Шевелева А. «Я не хочу ставить про то, как мы все умрем. Да, мы умрем, но зато как пожили!» // Известия. 2012. 27 мая.

Шин Янг Ми, 2002 - Шин Янг Ми. Женские образы в драматургии А.В. Вампилова. Москва. 2002. URL: http://cheloveknauka.com/ (дата обращения 27 05. 2016).

Segel, 1993 - Segel G. Twentieth-century Russian Drama: From Gorky to the Present. London, 1993. p. 412-420./ G. Segel Baltimore and London: Johns Hopkins University Press, 1993. $527 \mathrm{p}$.

Farber, 2001 - Farber $V$. The Playwright Aleksandr Vampilov: An Ironic Observer. New York and Oxford, Peter Lang, 2001. 225 p.

Farber, 2003 - Farber V. The Prose of Aleksandr Vampilov. New York and Oxford: Peter Lang, 2003. 189 p.

\section{References}

Bychkov, Man'kovskaya, 2017 - Bychkov V.V., Man'kovskaya N.B. (2017) Khudozhestvennost' kak metafizicheskoe osnovanie esteticheskogo opyta i kriteriy opredeleniya podlinnosti iskusstva [Artistisity as metaphysical foundation of aesthetic experience and criterion of art authenticity identification] Vestnik slavjanskih kul'tur. Vol. 43, p. 223.

$\mathrm{V}$ teatre $-\mathrm{V}$ teatre Komissarzhevskoy gotova $\mathrm{k}$ pokazu p'esa Aleksandra Vampilova "Prochlym letom v Chyulimske" [In the theater of Komissarzhevskaya a play "Last summer in Chulimsk" by Alexander Vampilov is ready to show] Retrieved from:http://tvkultura.ru/

Vlasova, 2013 - Vlasova, $T$ (2013). Kak ya provel "Proshlym letom v Chulimske" [How I spent "Last summerin Chulimsk"]. Novye Izvestia [News]. July 11.

Gushanskaya, 1990 - Gushanskaya, E.M. (1990). Aleksandr Vampilov. Ocherk tvorchestva [Alexander Vampilov: Essay on creativity] Sovetskiy pisatel'. Leningradskoe otdelenie [Soviet writer, Leningrad branch] Leningrad. Publ., 320 p, p. 87.

Eremina, 2016 - Eremina, M. "Proshlym letom v Chulimske" (Istoriya proshlogo leta) ["Last summerin Chulimsk" (History of last summer). Sait MKHT imeni A.P. Chekhova [The site of Moscow Art Theatre. A.P. Chehovayu]. Retrieved from: http://mxat.ru/

Ivanov, 2014 - Ivanov, V.V. (2014). Ob obnovlenii dokumentalnoy bazy russkogo teatra XX v. [On the renewal of the documentary base of the Russian theater of the XX century]. Vestnik Rossiyskogo gumanitarnogo nauchnogo fonda [Bulletin of the Russian Humanitarian Scientific Foundation]. No. 3 (76). pp. 168-175.

Klimtsev, 1976 - Klimtsev $V$ (1976). Retsenziruet chitatel' [The reader reviewing] Komsomolskaya Pravda. January 4. 
Krylova, 2004 - Krylova V.K. (2004). "Proshlym letom v Chulimske" ["Last summer in Chulimsk"] Vremen svyazuyusichaya nit'... Stranitsy istorii Russkogo dramaticheskogo teatra ot istokov do1990-kh godov [The Binding thread of times ... Pages of history of Russian Drama Theatre in Yakutia from theory gin still 1990-s]. Novosibirsk: Nauka [Science]. 380 p. pp. 255-263.

Kuznetsova, 2016 - Kuznetsova, N. M. (2016). Dva finala p'esy A.V. Vampilova "Prochlym letom v Chyulimske" (Opyt sravnitel'no-tekstologicheskogo analiza [Two finals of the play by A.V. Vampilov "Last summer in Chulimsk" (Experience of comparative-textual analysis)]. Retrieved from http://www.pandia.ru/

Kurova, 2012 - Kurova, N (2012). Novuyu versiyu p'esy "Prochlym letom v Chyulimske" pokazhet MKHAT im. Chekhova [The new version of the play "Last summerin Chulimsk" will show Chekhov's Moscow Art Theatre]. RIA Novosti. [RIA News]. June 1.

Mir Aleksandra, 2000 - Mir Aleksandra Vampilova: Zhizn'. Tvorchestvo. Sud'ba. (2000). [World Alexander Vampilov: Life. Creation. Fate]. Sostaviteli: L.V. Ioffe, S.R. Smirnov, i. dr. [Compilers L.V. Ioffe, S.R. Smirnov, and etc, Irkutsk. 448 p.

Motorin, 2002 - Motorin, S. N. (2002). Tvorchestvo Aleksandra Vampilova i russkaya dramaturgiya 80-90-kh godov XX veka. [Creativity of Alexander Vampilov and Russian drama in 80-90-ies of XX century].Philology Sciences Cand. Diss.. Moscow. 176 p. Retrieved from: http://www.dslib.

Nizhegorodskiy akademicheskiy - Nizhegorodskiy akademicheskiy teatr dramy imeni M. Gor'kogo. Otzyv na spektakl' "Proshlym letom v Chulimske" [Nizhny Novgorod Academic DramaTheatre named after Gorky. Review of the play "Last summer in Chulimsk] Retrieved from: http://nizhnii-novgorod.tulp.ru/teatry/

Nikityuk, 2000 - Nikityuk, T. V. (2000). "Prochlym letom v Chyulimske" ["Last summer in Chulimsk"] Mir Aleksandra Vampilova [World of Alexander Vampilov]. Irkutsk.

Ometsinskaya, 1975 - Ometsinskaya, E. (1975). Tam rubyat - tak s plecha [There hack - so with a shoulder] Nevskoe vremya [Neva time]. January 15.

Rasputin, 1992 - Rasputin, V.G. (1992). Gde ty, ducha zhiva? [Where are you, is a soul alive?]. Literatura $v$ chkole [Literature in the school]. Moscow, No. 2. pp. 30-33.

Rybakov, 1977 - Rybakov, Yu.S. (1977). G.A. Tovstonogov. Problemy rezhissury [G.A. Tovstonogov. Problems of direction] Leningrad: Iskusstvo. pp. 58-61.

Sait Vash - Sait Vash dosug [Website "Your leisure"] Retrieved from: http://www. vashdosug.ru/

Saltykov-Shchedrin, 1969 - Saltykov-Shchedrin, M. E (1969). Pic'ma iz provintsii. Pis'mo sed'moe. [Letters from the province. Letter Seven].Sobranie sochineniy v 20 tomakh. [Collected works in 20 volumes] Moscow. Fiction, T. 7, S. 258-270.

Sedykh, 1974 - Sedykh, M. (1974) Udivitel'nyy den' [Amazing day] Teatr [Theatre]. No. 9, S. 61.

Smirnov, 2006 - Smirnov, S.R. (2006). Dramaturgiya A. Vampilova: zakonomernosti tvorcheskogo protsessa [A. Vampilov's dramaturgy: the laws of the creative process]. Irkutsk. $317 \mathrm{~s}$.

Sobennikov, 2002 - Sobennikov, A.S. (2002). "Prochlym letom v Chyulimske" A. Vampilova: dva finala ["Last summer in Chulimsk" A. Vampilov: two finals]: Problemy literaturnykh zhanrov [Problems of literary genres]. Tomsk. Part 2. S. 184-188.

Spektakl - Spektakl' "Minulim litom v Chulimske". Kievskiy akademicheskiy dramaticheskiy teatr na Podole. [The play "Last summerin Chulimsk" or "Minulim litomv Chulimsku". Kyiv Academic Drama Theatre on Podil] Vse spektakli [All performances]. Retrieved from: http://www.theatre.ru/

Spektakl' Nyules - Spektakl' "Nyules kushyn lemlet syas'ka” [Performance "Nyules kushyn lemlet Syaska" ("Last summer in Chulimsk") Izhevsk]. Sait Bori-bilet [Izhevsk [Website Boris Ticket]. Retrieved from: http://www.borisbilet.ru/

Tovstonogov, 1980 - Tovstonogov, G.A. (1980). Zerkalo stseny No. 1 [The mirror of a scene]. Leningrad: Iskusstvo. No. 1, pp. 7-12.

Tovstonogov, 1980 - Tovstonogov, G.A. (1980). Zerkalo stseny No. 2. [The mirror of a scene]. Leningrad: Iskusstvo. pp. 9-10, 222-223.

Unichtozhit' $\mathrm{v}$ sebe - Unichtozhit' $\mathrm{v}$ sebe provintsiyu [Destroy a province in yourself]. Russian reporter 2009, No. 43. 11th of November. Retrieved from: http://www.rusrep.ru/ 2009/43/provincialnost_editorial/ 
Tsymbal, 1977 - Tsymbal, S. (1977). Oleg Borisov. Tvorcheskiy portret [Oleg Borisov. Creative portrait]. Teatr [Theatre] No. 10. p. 187.

Cherbaeva, 2014 - Cherbaeva, O.V. (2014). "Prirodnyy chelovek" v obraznoy structure p'esy "Proshlym letom v Chulimske" ["Man of nature" in the figurative structure of the play "Last summer in Chulimsk"] Filologocheskie nauki. Voprosy teorii i praktiki [Philology. Questions of theory and practice.]. Tambov. Gramota [Diploma]. No. 10 (40): v 3-kh chas'nyakh. Chas't' II. S. 198-201.

Sheveleva, 2012 - Sheveleva, A. (2012). "Ya ne khochu stavit' pro to, kak my vse umrem. Da, my umrem, no zato kak pozhili!" ["I do not want to set about how we're all going to die. Yes, we will die, but how we have lived!"]. Izvestiya [News]. May 27.

Shin Yang Mi, 2002 - Shin Yang Mi. (2002). Zhenskie obrazy v dramaturgii A.V. Vampilova [Female images in drama of A.V. Vampilov] Moscow. Retrieved from: http://cheloveknauka.com/

Segel, 1993 - Segel G. (1993). Twentieth-century Russian Drama: From Gorky to the Present. London: pp. 412-420. / G. Segel Baltimore and London: Johns Hopkins University Press, 1993. 527 p.

Farber, 2001 - Farber V. (2001). The Playwright Aleksandr Vampilov: An Ironic Observer. / V. Farber. New York and Oxford, Peter Lang. 225 p.

Farber, 2003 - Farber V. (2003). The Prose of Aleksandr Vampilov. New York and Oxford: Peter Lang. 189 p.

УДК 792.09; 792.03

\title{
Взаимодействие провинциальной драматургии и столичной сцены: историко-театроведческий аспект
}

\author{
Вера Климентевна Крылова ${ }^{\text {a , * }}$
}

а Институт Гуманитарных исследований и Проблем малочисленных народов Севера СО РАН, Российская Федерация

Аннотация. В статье впервые с учетом оценок ведущих режиссеров, и, что очень важно, зрительской аудитории, исследуется значимость творческого наследия драматурга А.В. Вампилова в театральном пространстве не только бывшего СССР, но и за рубежом. На основе историко-театроведческого анализа печатных источников, куда вошли и записи с репетиций, в частности, в Петербургском театре БДТ, А также заметок, особо ценных личных наблюдений, мнения корифея советской режиссуры Г.А. Товстоногова и других постановщиков о творчестве драматурга, раскрывается роль его исцеляющей провинциальной действительности наделенной «нравственной исповедальностью». Акцент на спектакле «Прошлым летом в Чулимске», автором сделан не случайно, Именно он своей жизнеутверждающей энергией оказывал особое психологическое воздействие не только на провинциальных, но и на столичных зрителей, о чем свидетельствуют их искренние отзывы. В заключение логически подчеркнута та благодатная роль вампиловской «советской глубинки», которая почти с детской непосредственностью воспринималась зрительской аудиторией и трансформировала поступки героев во внутренние чувства каждого сидящего в зале. Также нельзя не признать, что и сегодня мир «советской провинции» Вампилова не утратил своего значения. Он по-прежнему востребован, в нем нуждаются и театры, и зрители. Для одних он важен самобытным, многогранным, ярким художественным явлением в театральном пространстве, для других - исцеляющей чистотой человеческих чувств, испытав которые, «хочется обнять весь мир, творить, жить, любить и верить!»

Ключевые слова: драматургия А.В. Вампилова, спектакль «Прошлым летом в Чулимске», режиссер Г.А. Товстоногов, сценическое представление, зрительская психология, театральное искусство.

\footnotetext{
* Корреспондирующий автор

Адреса электронной почты: kvkrepressgur@mail.ru (В.К. Крылова)
} 